Jurnal Media Analis Kesehatan, Vol. 10, No.1, Juni 2019

http://journal.poltekkes-mks.ac.id/ojs2/index.php/mediaanalis

e-ISSN : 2621-9557

p-ISSN : 2087-1333

\title{
ANALISIS KADAR SERUM GLUTAMIC PYRUVIC TRANSAMINASE (SGPT) DAN SERUM GLUTAMIC OXALOACETIC TRANSAMINASE (SGOT) PADA PETANI YANG MENGGUNAKAN PESTISIDA
}

\author{
Widarti $^{1}$, Nurqaidah ${ }^{2}$ \\ 1,2 Jurusan Analis Kesehatan Poltekkes Makassar \\ Koresponden : widarti@poltekkes-mks.ac.id
}

\begin{abstract}
ABSTRAK
SGPT dan SGOT merupakan enzim yang keberadaan dan kadarnya dalam darah dijadikan penanda terjadinya gangguan fungsi hati. Enzim tersebut normalnya berada pada sel-sel hati. Kerusakan pada hati akan menyebabkan enzim-enzim hati tersebut lepas ke dalam aliran darah sehingga kadarnya dalam darah meningkat dan menandakan adanya gangguan fungsi hati. Hati merupakan salah satu organ target pestisida. Akumulasipenggunaan pestisida jika masuk kedalam hati tidak dapat diuraikan serta dieksresikan dan tersimpan dalam hati akan menyebabkangangguan sel atau organel hati. Hal ini mengakibatkan kerusakan padaparenkim hati atau gangguan permeabilitas membran sel hati sehingga enzim bebas keluar sel.Sebagai respon terhadap kerusakan pada hati maka konsentrasi enzim dalam darah akan meningkat. Tujuan penelitian ini adalah untuk menganalisis gambaran kadar SGPT pada petani yang menggunakan pestisida, dan untuk menganalisis gambaran kadar SGOT pada petani yang menggunakan pestisida. Penelitian ini dilakukan di RSUD Pangkep pada tanggal 22 Februari s/d 10 April 2018 dengan jumlah sampel penelitian sebanyak 10 subjek. Hasil analisa data presentase pada pemeriksaan SGPT dan SGOT didapatkan hasil yaitu kadar SGPT normal sebesar 100\% dan tidak normal sebesar 0\%, kadar SGOT normal sebesar $90 \%$ dan tidak normal sebesar $10 \%$.
\end{abstract}

Kata Kunci $=$ SGPT, SGOT, Pestisida

\section{PENDAHULUAN}

Bidang pertanian memiliki angkatan kerja terbesar di Indonesia. Menurut data hasil sensus pertanian tahun 2003, sekitar 25,6 juta kepala keluarga bertumpu dan bermata pencaharian pertanian. Permasalahan yang sering dihadapi para petani salah satunya adalah gangguan atau dirusaknya tanaman pertanian mereka oleh organisme pengganggu yang secara ekonomis sangat merugikan petani.
Organisme pengganggu tanaman/ tumbuhan ini dikenal sebagai hama tanaman, penyakit tanaman, dan gulma (tumbuhan pengganggu). Dalam upaya meningkatkan mutu dan produktifitas hasil pertanian, penggunaan pestisda untuk membasmi hama tanaman sering tidak dihindarkan (Sulistyoningrum SCD, 2008).

Banyak zat kimia yang dipakai dalam pertanian, misalnya pupuk yang mengandung nitrogen dan sulfur, 
Jurnal Media Analis Kesehatan, Vol. 10, No.1, Juni 2019

http://journal.poltekkes-mks.ac.id/ojs2/index.php/mediaanalis

e-ISSN : 2621-9557

p-ISSN : 2087-1333

pestisida (pemeliharaan tanah dan benih), pengatur pertumbuhan tanaman, desinfektan obat-obatan untuk hewan (termasuk pemberian antibiotic untuk hewan. Diantara semua hal diatas pestisida merupakan zat kimia yang dipakai untuk mengendalikan atau membasmi hama.

Pestisida atau pembasmi hama adalah bahan yang digunakan untuk mengendalikan, menolak, atau membasmi organisme pengganggu. (Wikipedia, 2017).

Pestisida digunakan untuk meningkatkan hasil pertanian dan megurangi serangan hama tanaman sehingga mendorong petani petani untuk menggunakan pestisida dengan komposisi, takaran, dan frekuensi menyemprot dilakukan tanpa perhitungan yang benar dan pada akhirnya menimbulkan berbagai masalah baru, terutama masalah kesehatan pada petani itu sendiri.

Kita ketahui bahwa masuknya racun kedalam tubuh dapat melalui beberapa cara diantaranya melalui dermal (kulit), jalur inhalasi (pernafasan) dan jalur ingesti (melalui makanan dan minuman). Realita dilapangan para petani kurang menyadari daya racun pestisida sehingga dalam melakukan penyimpanan dan penggunaannya tidak memerhatikan keselamatan. Petani sebagai pekerja yang biasa kontaminasi dengan pestisida secara langsung mempunyai risiko yang lebih tinggi. Risiko penggunaan pestisida secara langsung dapat terjadi tidak hanya saat melakukan penyemprotan, namun dapat pula terjadi saat proses mempersiapkan hingga saat setelah melakukan penyemprotan. Kurangnya kesadaran petani untuk menggunakan alat pelindung diri (APD) saat melakukan penyemprotan menjadi faktor risiko terjadinya keracunan. Petani dapat mengalami pusing, iritasi pada kulit, mata berair, pingsan, hingga menyebabkan kematian. Hal tersebut dapat disebabkan kurangnya kesadaran keselamatan kerja dan kesadaran akan bahaya racun dari pestisida yang digunakan (Ipmawati PA dkk, 2016).

Hati merupakan salah satu organ target pestisida. Akumulasi penggunaan pestisida jika masuk kedalam hati tidak dapat diuraikan serta dieksresikan dan tersimpan dalam hati akan menyebabkan gangguan sel atau organel hati. Hal ini mengakibatkan kerusakan pada parenkim hati atau gangguan permeabilitas membran sel hati sehingga enzim bebas keluar sel. Sebagai respon terhadap kerusakan pada hati maka konsentrasi enzim dalam darah akan meningkat.

Alanine aminotransferase (ALT) atau Serum Glutamic Pyruvic transaminase (SGPT) dan Aspartate aminotransferase (AST) atau Serum Glutamic Oxsaloasetic transaminase (SGOT), merupakan enzim yang keberadaan dan kadarnya dalam darah dijadikan penanda terjadinya gangguan fungsi hati. Enzim tersebut normalnya berada pada sel-sel hati. Kerusakan pada hati akan menyebabkan enzimenzim hati tersebut lepas ke dalam aliran darah sehingga kadarnya dalam darah meningkat dan menandakan adanya gangguan fungsi hati (Tsani RA dkk, 2017).

Berdasarkan uraian diatas peneliti telah melakukan penelitian mengenai 
Analisis Kadar SGPT dan SGOT pada Petani yang Menggunakan Pestisida.

\section{METODE}

Jenis penelitian yang digunakan adalah jenis penelitian deskriptif. Penelitian dilaksanakan pada bulan Februari- April 2018 di Laboratorium Rumah Sakit Umum Daerah Pangkep.

Sampel yang digunakan dalam penelitian ini yaitu sebanyak 10 sampel. Pengambilan sampel secara purposive sampling. Adapun kriteria sampel Kriteria Inklusi yaitu Petani yang menggunakan pestisida selama lebih dari 18 tahun, Petani yang tidak memiliki riwayat penyakit hati, Petani yang tidak mengkonsumsi obat-obatan dan zat yang dapat mempengaruhi kadar SGPT dan SGOT, misalnya salisilat dan alcohol, Petani yang tidak menggunakan APD dan Petani yang bersedia menjadi subjek penelitian dan bersedia untuk mengisi informed consent.

Bahan penelitian yang digunakan dalam penelitian ini adalah serum, alkohol 70\%, reagen mindray GPT dan GOT. Sedangkan Instrumen yang digunakan yaitu : spoit, kapas alkohol $70 \%$, clinipet $500 \mu \mathrm{l}$, tabung vacum, rak tabung, sentrifus, alat Mindray, kuvet serta alat pelindung diri yang terdiri dari jas laboratorium, masker, dan handscoon.

Prosedur Penelitian

1. Pra Analitik:

a. Persiapan pasien

1) Hindari latihan fisik yang berat sebelum pengambilan sampel

2) Hindari obat atau zat yang dapat mempengaruhi kadar GPT dan
GOT misalnya salisilat dan alkohol.

b. Pengambilan sampel penelitian

Prosedur pengambilan darah vena

1) Dibersihkan bagian lengan yang akan ditusuk dengan kapas alkohol $70 \%$ dan dibiarkan sampai kering.

2) Jika memakai vena dalam fossa cubiti, dipasang ikatan pembendung pada lengan atas dan diminta pasien untuk mengepalkan dan membuka tangannya berkali-kali agar vena terlihat jelas.

3) Ditegangkan kulit diatas vena dengan jari-jari tangan kiri agar vena tidak dapat bergerak.

4) Ditusuk kulit dengan jarum dan spoit dalam tangan kanan sampai ujung jarum masuk ke dalam pembuluh vena.

5) Dilepaskan atau diregangkan pembendungan dan perlahanlahanlah tarik penghisap semprit sampai jumlah darah yang dikehendaki didapat.

6) Dilepaskan pembendungan jika masih terpasang.

7) Ditaruh kapas diatas jarum dan dicabut spoit dan jarum itu.

8) Diminta kepada pasien agar tempat tusukan itu ditekan selama beberapa menit dengan kapas tadi.

9) Diangkat atau dilepaskan jarum dari spoit dan darah dialirkan ke dalam wadah atau tabung yang tersedia melalui dinding (Gandasoebrata R, 2011).

c. Persiapan sampel 
1) Darah vena di sentrifus untuk memisahkan seldarah merah dengan serum.

2) Sampel dihindarkan dari halhal yang dapat menyebabkan hemolisis.

2. Analitik:

a. Pengerjaan sampel untuk pemeriksaan kadar SGPT dilakukan prosedur yaitu;

1) Ditekan on/off, periksa washer, rinse, rak kuvet, reagen dan dilakukan kontrol sebelum alat digunakan, setelah semua selesai alat siap dioperasikan.

2) Diambil serum dengan menggunakan clinipet $500 \mu \mathrm{l}$.

3) Dimasukkan sampel ke dalam sampel disk. Diberi label sesuai identitas pasien.

4) Diletakkan cup sampel pada rak sampel.

5) Diklik menu sampel pada display.

6) Dipilih sampel request.

7) Dicek posisi sampel pada sampel disk apakah sesuai.

8) Diinput data pasien.

9) Dipilih parameter yang akan diperiksakan lalu tekan ok.

10) Ditekan ikon play maka secara otomatis proses run sampel akan bekerja.

11) Hasil muncul, ditekan print untuk mencetak hasil.

b. Pengerjaan sampel untuk pemeriksaan kadar SGOT dilakukan prosedur yaitu;

1) Ditekan on/off, periksa washer, rinse, rak kuvet, reagen dan dilakukan kontrol sebelum alat digunakan, setelah semua selesai alat siap dioperasikan.

2) Diambil serum dengan menggunakan clinipet 500 $\mu \mathrm{l}$.

3) Dimasukkan sampel ke dalam sampel disk. Diberi label sesuai identitas pasien.

4) Diletakkan cup sampel pada rak sampel.

5) Diklik menu sampel pada display.

6) Dipilih sampel request.

7) Dicek posisi sampel pada sampel disk apakah sesuai.

8) Diinput data pasien.

9) Dipilih parameter yang akan diperiksakan lalu tekan ok.

10) Ditekan ikon play maka secara otomatis proses run sampel akan bekerja.

11) Hasil muncul, ditekan print untuk mencetak hasil.

3. Pasca analitik:

a. Pencatatan hasil

b. Pengelolaan data

Analisis Data

Hasil penelitian ini kemudian akan dianalisa dengan disajikan menggunakan tabel kemudian dihitung persentasinya

\section{HASIL}

Berdasarkan hasil penelitian, yakni pemeriksaan kadar SGPT dan SGOT pada petani yang menggunakan pestisida didapatkan hasil sebagai berikut: 
Jurnal Media Analis Kesehatan, Vol. 10, No.1, Juni 2019

http://journal.poltekkes-mks.ac.id/ojs2/index.php/mediaanalis

e-ISSN : 2621-9557

p-ISSN : 2087-1333

Tabel 1. : Hasil pemeriksaan kadar SGPT dan SGOT pada petani yang menggunakan pestisida.

\begin{tabular}{ccccc} 
NO. & Kode Sampel & \multicolumn{2}{c}{ Hasil Pemeriksaan } & Satuan \\
\cline { 3 - 4 } & & SGPT & SGOT & \\
\hline 1. & $\mathrm{~A}$ & 23,2 & 65,2 & $\mathrm{U} / \mathrm{L}$ \\
2. & $\mathrm{~B}$ & 16,0 & 24,0 & $\mathrm{U} / \mathrm{L}$ \\
3. & $\mathrm{C}$ & 20,6 & 27,2 & $\mathrm{U} / \mathrm{L}$ \\
4. & $\mathrm{D}$ & 29,0 & 21,0 & $\mathrm{U} / \mathrm{L}$ \\
5. & $\mathrm{E}$ & 23,2 & 20,6 & $\mathrm{U} / \mathrm{L}$ \\
6. & $\mathrm{~F}$ & 17,0 & 12,0 & $\mathrm{U} / \mathrm{L}$ \\
7. & $\mathrm{G}$ & 5,2 & 19,9 & $\mathrm{U} / \mathrm{L}$ \\
8. & $\mathrm{H}$ & 13,7 & 11,5 & $\mathrm{U} / \mathrm{L}$ \\
9. & $\mathrm{I}$ & 16,0 & 19,7 & $\mathrm{U} / \mathrm{L}$ \\
10. & $\mathrm{~J}$ & 18,7 & 30,8 & $\mathrm{U} / \mathrm{L}$ \\
\hline
\end{tabular}

Nilai normal:

- SGPT : $<40$

- SGOT : $<38$

Tabel diatas menunjukkan bahwa hasil pemeriksaan yang telah dilakukan dari 10 sampel

hanya satu sampel yang mengalami peningkatan yaitu pada kode sampel A pemeriksaan SGOT.

Tabel 2: Hasil pemeriksaan kadar SGPT dan SGOT

\begin{tabular}{cccccc}
\hline \multirow{2}{*}{ No. } & \multirow{2}{*}{ Kode Sampel } & \multicolumn{4}{c}{ Hasil Pemeriksaan (U/L) } \\
\cline { 3 - 6 } & & SGPT & Ket. & SGOT & Ket. \\
\hline 1. & $\mathrm{~A}$ & 23,2 & $\mathrm{~N}$ & 65,2 & $\mathrm{TN}$ \\
2. & $\mathrm{~B}$ & 16,0 & $\mathrm{~N}$ & 24,0 & $\mathrm{~N}$ \\
3. & $\mathrm{C}$ & 20,6 & $\mathrm{~N}$ & 27,2 & $\mathrm{~N}$ \\
4. & $\mathrm{D}$ & 29,0 & $\mathrm{~N}$ & 21,0 & $\mathrm{~N}$ \\
5. & $\mathrm{E}$ & 23,2 & $\mathrm{~N}$ & 20,6 & $\mathrm{~N}$ \\
6. & $\mathrm{~F}$ & 17,0 & $\mathrm{~N}$ & 12,0 & $\mathrm{~N}$ \\
7. & $\mathrm{G}$ & 5,2 & $\mathrm{~N}$ & 19,9 & $\mathrm{~N}$ \\
8. & $\mathrm{H}$ & 13,7 & $\mathrm{~N}$ & 11,5 & $\mathrm{~N}$ \\
9. & $\mathrm{I}$ & 16,0 & $\mathrm{~N}$ & 19,7 & $\mathrm{~N}$ \\
10. & $\mathrm{~J}$ & 18,7 & $\mathrm{~N}$ & 30,8 & $\mathrm{~N}$ \\
\hline
\end{tabular}

Keterangan:

- N : Normal

- TN : Tidak Normal

Dari hasil penelitian yang diperoleh seperti yang tercantum pada tabel 2, selanjutnya diolah dengan teknik analisa secara

deskriptifdalam pengolahan mencakup hasil presentase SGPT dan SGOT yaitu sebagai berikut: 
Tabel 3 : Hasil persentase pemeriksaan SGPT dan SGOT

\begin{tabular}{ccc}
\hline Pemeriksaan & \multicolumn{2}{c}{ Hasil Persentase } \\
\cline { 2 - 3 } & Normal & Tidak Normal \\
\hline SGPT & $100 \%$ & $0 \%$ \\
SGOT & $90 \%$ & $10 \%$
\end{tabular}

\section{PEMBAHASAN}

SGPT/ALT adalah enzim yang spesifik untuk hati yang hanya memberikan hasil yang signifikan terhadap adanya peningkatan penyakit hepatobilliary di hati. SGOT/AST adalah enzim yang tidak spesifik hanya terdapat di dalam hati tetapi juga dapat di temukan di sel darah, sel jantung dan sel otot, oleh karena itu peningkatan SGOT tidak selalu menunjukkan adanya kelainan di sel hati.

Penelitian ini dilaksakan di Laboratorium RSUD Pangkep yang dimulai pada tanggal 22 Februari s/d 10 April 2018 dengan subyek penelitian sebanyak 10 orang petani.

Interpretasi nilai normal yang dilakukan peneliti menggunakan nilai nirmal laboratorium RSUD Pangkep yaitu dengan nilai $\mathrm{SGPT}<40 \mathrm{U} / \mathrm{L}$ dan nilai SGOT $<38 \mathrm{U} / \mathrm{L}$.

Berdasarkan hasil penelitian terhadap 10 sampel mengenai analisis kadar SGPT dan SGOT pada petani yang menggunakan pestisida meliputi: pada pemeriksaan SGPT tidak ada yang mengalami peningkatan dari 10 sampel, dan pemeriksaan SGOT yang tidak mengalami peningkatan sebanyak 9 sampel dan yang mengalami peningkatan sebanyak 1 sampel. Kadar SGPT normal sebesar $100 \%$ dan tidak normal sebesar 0\%, kadar SGOT normal sebesar $90 \%$ dan tidak normal sebesar $10 \%$.

Kadar SGPT dan SGOT meningkat pada kerusakan parenkim hati, juga meningkat pada hepatitis akut, hepatotoksisitas yang menyebabkan nekrosis hepar (toksisitas obat dan kimia)sedangkan agak meningkat pada sirosis hati, kanker hepar, gagal jantung kongestif, intoksikasi alkohol akut, peningkatan marginal, infark miokardio akut.

Kadar SGPT dan SGOT pada petani dikatakan normal karena semua bahan kimia berupa nutrien dan xenobiotik (misalnya pestisida) yangterkandung dalam darah akan dimetabolisme dan dibiotrasformasi oleh hati. Proses biotransformasi xenobiotik (misalnya pestisida) oleh hati yang berlangsung baik akan menurunkan bahkan menghilangkan kadarnya dalam darah yang yang keluar dari hati sebelum mencapai organ lainnya. 
Jurnal Media Analis Kesehatan, Vol. 10, No.1, Juni 2019

http://journal.poltekkes-mks.ac.id/ojs2/index.php/mediaanalis

e-ISSN : 2621-9557

p-ISSN : 2087-1333

Proses biotransformasi akan merubah xenobiotik menjadi bentuk lain dengan tujuan agar (1) menjadi inaktif secara biologis sehingga tidak memberikan efek buruk terhadap tubuh, (2) menjadi lebih polar dan lebih mudah larut pada air sehingga lebih mudah diekskresikan ke luar tubuh (Siwiendrayanti A, 2009).

Proses biotransformasi yaitu:

1. Reaksi fase I (Reaksi penguraian), yaitu: pemutusan hidrolitik, oksidasi dan reduksi. Umumnya reaksi fase I mengubah bahan yang masuk ke dalam sel menjadi lebih bersifat hidrofilik (mudah larut dalam air) daripada bahan asalnya.

2. Reaksi fase II (Reaksi konjugasi), terdiri dari reaksi sintesis dan konjugasi. Oleh reaksi konjugasi maka zat yang memiliki gugus polar ($\mathrm{OH}, \quad-\mathrm{NH} 2, \quad-\mathrm{COOH}$, dikonjugasi dengan pasangan reaksi yang berasal dari tubuh sendiri dan lazimnya diubah menjadi bentuk yang larut dalam air, dan dapat diekskresikan dengan baik oleh ginjal. Reaksi fase II ini merupakan proses biosintesis yang mengubah bahan asing atau metabolit dari fase I membuat ikatan kovalen dengan molekul endogen menjadi konjugat (Hayat F, 2010).

Kadar SGPT serum dapat lebih tinggi dari kadar sekelompok transferase lainnya (transminase), aminotransferase aspartat (aspartate aminotransferase) AST / serum glutamic oxatoacetic transminase (SGOT), dalam kasus hepatitis akut serta kerusakan hati akibat penggunaan obat dan zat kimia, dengan stiap serum mencapai 200-4000 U/L.

Kadar SGOT serum tinggi dapat ditemukan setelah terjadi Infark Miokardium (MI) akut dan kerusakan hati.Pada penyakit hati, kadar serum akan meningkat 10 kali atau lebih dan tetap demikian dalam waktu yang lama (Kee JL, 2007).

Kadar SGPT seringkali dibandingkan dengan SGOT untuk tujuan diagnostik. SGPT meningkat lebih khas daripada SGOT pada kasus nekrosis hati dan hepatitis akut, sedangkan SGOT meningkat lebih khas dari pada nekrosis miokardium (infark miokardium akut) sirosis, kanker hati, hepatitis kronis dan kongesti hati. Kadar SGOT ditemukan normal atau meningkat sedikit pada kasus nekrosis miokardium. Kadar SGPT kembali lebih lambat ke kisaran normal daripada kadar SGOT pada kasus hati.

Pada salah satu sampel pemeriksaan SGOT dalam penelitian ini terjadi peningkatan, peningkatan tersebut dapat disebabkan karena faktor kelelahan akibat aktivitas yangberat dan juga SGOT tidak spesifik hanya terdapat di dalam hati. SGOT juga di temukan di sel darah, sel jantung dan sel otot, oleh karena itu peningkatan SGOT tidak selalu 
Jurnal Media Analis Kesehatan, Vol. 10, No.1, Juni 2019

http://journal.poltekkes-mks.ac.id/ojs2/index.php/mediaanalis

e-ISSN : 2621-9557

p-ISSN : 2087-1333

menunjukkan adanya kelainan di sel hati.Oleh karena itu diperlukan pemeriksaan SGPT juga, ketika kedua enzim ini meningkat maka sudah dapat dipastikan adanya kerusakan pada sel hati.

Pada penelitian ini memiliki banyak kekurangan yaitu pada kriteria sampel penelitian, seharusnya lebih diperhatikan dan ditambah dengan kriteria lain seperti lama penyemprotan dan jumlah pestisida yang digunakan.

\section{KESIMPULAN}

Berdasarkan hasil penelitian yang dilaksanakan di Laboratorium RSUD Pangkep pada tanggal 22 Februari s/d 10 April 2018 dapat disimpulkan bahwa kadar SGPT normal sebesar $100 \%$ dan tidak normal sebesar $0 \%$, kadar SGOT normal sebesar $90 \%$ dan tidak normal sebesar $10 \%$ dengan jumlah sampel yang digunakan sebanyak 10 subjek.

\section{SARAN}

Untuk peneliti selanjutnya, diharapkan dapat melanjutkan penelitian ini dengan menambah jumlah sampel serta memperhatikan lama penyemprotan dan jumlah pestisida yang digunakan

\section{DAFTAR PUSTAKA}

Gandasoebrata R. 2011. Penuntun Laboratorium Klinik. Jakarta: Dian Rakyat.

Hayat F. 2010. Biotransformasi toksikan.

(https://fadhilhayat.wordpress. com/2010/10/06/biotransforma si-toksikan/). Diakses tanggal 02 Juni 2018

Ipmawati PA, Setiani O, Darundiati YH. 2016. Analisis FaktorFaktor Risiko yang Mempengaruhi Tingkat Keracunan Pestisida Pada Petani di Desa Jati, Kecamatan Sawangan, Kabupaten Magelang, Jawa Tengah. (https://media.neliti.com/media /publications/18513-IDanalisis-faktor-faktor-risikoyang-mempengaruhi-tingkatkeracun an-pestisida-pada.pdf). Diakses pada tanggal 04 Desember 2017.

Kee JL. 2007. Pedoman Pemeriksaan Laboratorium \& Diagnostik. Jakarta: EGC.

Siwiendrayanti A. 2009. Hubungan Riwayat Pajanan Pestisida Dengan Kejadian Gangguan Fungsi Hati Pada Wanita Usia Subur (WUS) di Desa Sutamaja Kecamatan Kersana Kabupaten Brebes.

(https://www.researchgate.net/p rofile/Arum_Siwiendrayanti/pu blication/278158749_HUBUN GAN_RIWAYAT_PAJANAN PESTISIDA_DENGAN_KEJ ADIAN_GANGGUAN_FUNG SI_HATI_PADA_WANITA USIA_SUBUR_WUS_DI_DE SA_SUTAMAJA_KECAMAT AN_KERSANA_KABUPATE N_BREBES/links/55f7f22f08a eba1d9f004f56.pdf). Diakses pada tanggal 04 Desember 2017.

Sulistyoningrum $\quad 2008$. Gangguan Kesehatan Akut 
Jurnal Media Analis Kesehatan, Vol. 10, No.1, Juni 2019

http://journal.poltekkes-mks.ac.id/ojs2/index.php/mediaanalis

e-ISSN : 2621-9557

p-ISSN : 2087-1333

Akibat Pestisida di Desa

Kedung Rejo Kecamatan

Megaluh Kabupaten Jombang.

(https://repository.usd.ac.id/245

8/2/038114 048_Full.pdf).

Diakses pada tanggal 28

November 2017.

Tsani RA, Setiani O, Dewanti NAY. 2017. Hubungan Riwayat Pajanan Pestisida dengan Gangguan Fungsi Hati Pada
Petani di Desa Sumberejo Kecamatan Ngablak Kabupaten Magelang.

(http://ejournal3.undip.ac.id/ind ex.php/jkm/article/download/1 7258/16516). Diakses pada tanggal 28 Desember 2017.

Wikipedia. $2017 . \quad P e s t i s i d a$. (https://id.wikipedia.org/wiki/P estisida\# Sejarah). Diakses pada tanggal 04 Desember 2017. 